\title{
ニューラルネットワークを用いた大阪湾内への 来襲津波のリアルタイム予測に関する研究
}

\author{
Real-time Prediction of Tsunami Propagating into the Osaka Bay by \\ Using Artificial Neural Network
}

\author{
間瀬 肇 $^{1} \cdot$ 安田誠宏 ${ }^{2} \cdot$ 高山知司 $^{3}$
}

Hajime MASE, Tomohiro YASUDA and Tomotsuka TAKAYAMA

\begin{abstract}
This study examines the validity to use an artificial neural network (ANN) for the prediction of tsunami magnitudes at several locations in the Osaka Bay by using observed water surface elavations of 20 minumites, at the tower of Shirahama Oceanographic Observatory. The tsunami data used as training and test data for ANN were simulated for different fault models considering tsunami source non-uniformity. The linear activation function was found to be a good choice for output units and the tangent sigmoid function for hidden layer's units. For the training of ANN the Levenberg-Marquardt method with Bayesian regulation were employed. Outputs from the trained network such as the first and the second sea surface falls and rises agreed well with the results of tsunami simulations at each location and all five locations.
\end{abstract}

\section{1.はじめに}

近い将来，南海地震と東南海地震の巨大地震が発生す ると指摘されている，震源域に海域を含む地震は，津波 も発生させるので，地震被害と津波被害の 2 重の被害が 生じる. 気象庁の津波予報は, 日本近海の様々な場所に 様々な規模の地震モデルを想定して津波シミュレーショ ンを行い, それらの計算結果のデータベースを利用して, 地震が起きた場合, 推定された震源位置とマグニチュー ドに最も近い地震に対する計算結果を選び出して，予想 される津波の高さを予報するものである.

津波予報区は原則として府県単位（66 予報区）であ り，沿岸地形の特性を考慮できるほど細分化されていな い, 和歌山下津港や大阪湾内の各港では, 津波の到達ま で時間が比較的あるため，この間に的確な津波情報を得 ることができれば，港湾管理者あるいは港湾事業者は諸 対策を適切に講ずることが可能となる.

安田ら $(2004 ， 2005)$ は，気象庁の予報を補完するもの として, 地震発生後の津波の観測デー夕を用いて, リア ルタイムで大阪湾内に来襲する津波を予測する手法の開 発をしている. 本研究は, 安田らの研究と目的は同じで あるが, 来襲津波の時間波形までの情報は無視し, 水位 の最大上昇量と低下量をすばやく予測するシステムとし て，ニューラルネットワークを援用するリアルタイム津 波予測法の検討を行うものである.

1 正会 員 工博

2 正会員 博(工)

3 フェロー 工博
京都大学教授 防災研究所 京都大学助教 防災研究所 (財)沿岸技術研究センター 沿岸防災技術 研究所長

\section{2. ニューラルネットワークの概要}

\section{（1）モデルの概要および応用例}

人間の脳の情報処理システムは並列分散処理を行って おり，階㽚構造を持っている.ニューラルネットワーク 情報処理は，そうした脳の情報処理をモデルとしたもの である，人間の神経細胞（ニューロン）のモデルを用い た人工システムはニューロ，ニューロンの人工モデルは ユニットと呼ばれる。

あるデー夕間の因果関倸が不明確で，入出力関係のプ ログラム化は不可能である場合など，ニューラルネット ワークではユニットをシプナスで結びつけ, 繰り返し学 習によりその結合度を変化させ，入出力関係を具現化す ることが可能である，したがって，ネットワークを形成 する過程でプログラム化が内部的に行われ，因果関係の 解析方困難なデー夕を処理する上で極めて有効である.

海岸工学の分野でニューラルネットワークを応用した 研究には, 混成防波堤に打ける衝撃砕波力の発生判定, 捨石防波堤の安定性評価, 消波ブロック被覆工の変形量 評価，越波流量の算定(例えば，間瀬ら,1994；2005)， 潮位予測 (Deo, 1998) や波浪予測(Deo, 1999) 等がある。

\section{(2) ニューラルネットワークの構成}

$$
\text { ニューロで通常用いられるモデル(ユニット)は, 多入 }
$$
カ・1出力といった非常に簡略化されたモデルが用いられ る. ユニット間は神経䄉維に対応する線(シプナス)で結ば れ，信号は一方向に伝わる. ユニットにつながっているシ プナスからの入力信号は，ある重み(結合荷重)をかけられ 加算され，さらに闌值が差し引かれた值がそのユニットに 入力される. ユニットは応答関数に応じた值を出力する.

多層ネットワークに扩けるユニットの応答関数として, 


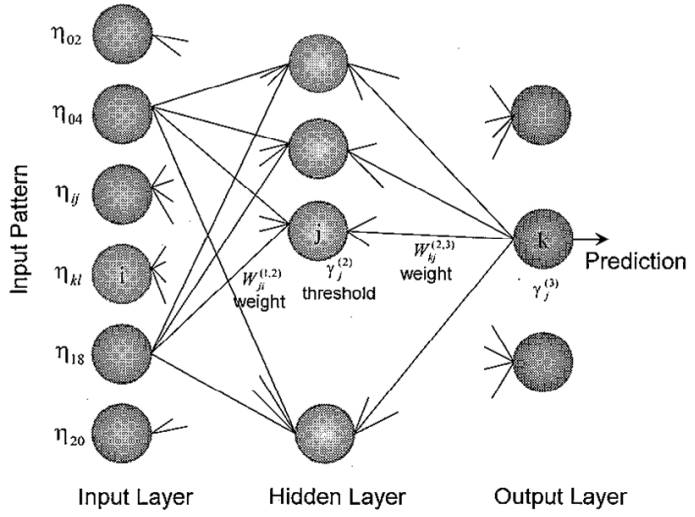

図-1 階層型ネットワーク

しばしば用いられるのはシグモイド関数である。シグモ イド関数には, 出力が $0 \sim 1$ の $\log$ 型と出力が $-1 \sim 1$ の tangent 型がある. 多層ネットワークに扔いて, 最後 の層がシダモイドニューロンの場合，ホットワークの出 力值が制限される. そのため, 線形関数が出力ニューロ ンに用いられることがある。これにより，ネットワータ の出力が任意となる. 実際の応用には, 図-1の階層型 ネットワークがよく用いられる.

\section{（3）学 習 法}

階層型ネットワークは, 入力層, 中間層, 出力層から なる. 入力層に与えられるデータは，入力パターンと呼 ばれる，入力パターンと同時に，学習の指針として望ま しい出力值 (教師信号) を与え, ネットワークからの出 力信号と教師信号との鿁差をフィードバックすることに より，教師信号に近い值がでるようにネットワークを調 整する学習法がある. 学習によって得られる知識は, 結 合荷重と閾值に蓄えられる。バックプロパゲーションは こうした教師付き学習法のことである.

本研究では, 入力パターンとして後に示す地震発生後 京都大学防災研究所白浜観測塔で観測される 2 分ごとの 水位データを用いる. 出力值としては, 大阪湾内の 1 つ の対象地点, あるいは, 多地点に抢ける最大水位上昇量 と低下量を用いる.

バックプロパゲーションアルゴリズムには多くの種類 があるが, 最も単純なバックプロパゲーション学習は, パフォーマンス関数（ネットワーク出力とターゲット出 力の間の平均二乗誤差) が最も早く減少する勾配の負方 向に経路の重みと閾值を更新する勾配降下法である.

本研究では, 数值最適化手法に基づく高速訓練アルゴ リズムである共役勾配法のうち, Levenberg-Marquardt 法（LM 法）を用いて，学習の高速化を図る.

ニューラルネットワークの訓練中に起きる問題の一つ に, 過学習 (オーバーフィティング) が挙げられる.こ
れは訓練データセットに対する適合度が良くなり過ぎ， 新規のデータセットに対してかえって誤差が大きくなる 現象である.一般化の改良方法としては，早期停止と正 則化を用いる。

早期停止法では, 利用可能なデータを 3 つのサブセッ トに分割する.1つ目のサブセットは訓練データセットで あり,ネットワークの訓練に用いる.2つ目のサブセットは バリデーションデータセットである. バリデーションデ ータセットに対する誤差は, 訓練データセットに対する 誤差と同様に, 訓練の初期フェーズ中に通常減少するが, ネットワークが訓練データセットにオーバーフィットし 始めるとバリデーションデータセットに対する䛊差は増 加し始める.そこで,バリデーションデータセットに対す る愦差が最小になったときに訓練を停止させる．3つ目の サブセットはテストデータセットである。訓練中には用 いないが,ネットワークの妥当性を検証するために用いる。 正則化法においては, ネットワーク誤差の平均二乗和 であるパフォーマンス関数に，ネットワークの重みの平 均 2 乗和を加えることによって，一般化の改良を行う. 自動化された最適正則化法として Bayesian 法がある.

本研究では, 用いるケース数が少ないことからサブセ ットに分けなくても良いBaysian 正則化法を用いる.

\section{3. ニューラルネットワークに用いる津波計算結果}

\section{（1）リアルタイム津波予測}

本研究で検討するリアルタイム津波予測は，大阪湾外 あるいは外洋における観測デー夕を用いて，大阪湾内に 来襲する津波を予測するものである。ここでは，地震発 生後に京都大学防災研究所白浜観測塔の波形デー夕が得 られたと仮定し，その時間波形を用い，ニューラルネッ トワークにより，1〜1.5 時間後に湾内に到達する津波 を予測する. 図-2に, 白浜観測塔と津波予測対象地点 の位置図を示す。

\section{(2) 想定津波}

河田ら (2003)の研究による不均一性を導入した波源を 用いた津波計算結果を，観測された津波波形として用い る. 不均一性は, 地震規模, 地震規模とアスペリティ, および，地震規模とアスペリティと断層形状を考慮した 断層モデルによって考慮される.また, 地震规模のみを 考慮した(地震モーメントを地震調査研究推進本部の震 源域モデル (2001)のそれと等しく補正する) Ando モデ ル(1975)と相田モデル（1981）に対する津波シミュレーシ ヨン結果を用いる.

図-3は，規模を考慮したAndo モデルによる津波計 算結果を示したものでありこうした一連のシミュレー ション結果から白浜観測塔における地震発生後 20 分間 の時間波形㧍よび大阪湾内の神戸港, 尼崎港, 大阪港, 




图-2 白浜観測塔と津波予測対象地点

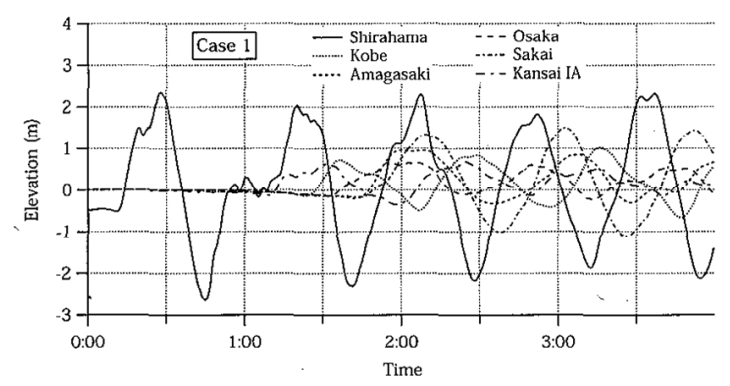

図-3＼cjkstart規模を考慮したAndo モデルによる津波計算結果

堺泉北港抢よび関西空港の 5 地点における水位の最大上 昇量と低下量を求めた。

図-4の上段は，異なる5 ケースの白浜観測所におけ る 20 分間の時間波形, 図-4の下段は神戸港, 尼崎港, 大阪港, 堺泉北港, 関西空港における第 1 波水位低下量, 第 1 波水位上昇量, 第 2 波水位低下量, 第 2 波水位上昇 量を示したものである。これらのケースは, 河田ら (2003) の B-W-1-20, B-W-1-25, B-W-2-20, B-W2-25, C-E-1に対応する.

テストケースは, Case A：1707 年宝承東海・南海地 震 (相田モデル, 1981), Case B：1946 年昭和南海地震 （相田モデル，1981）, Case C：中央防災会議による東 南海・南海地震モデル（2001）による津波シミュレーシ
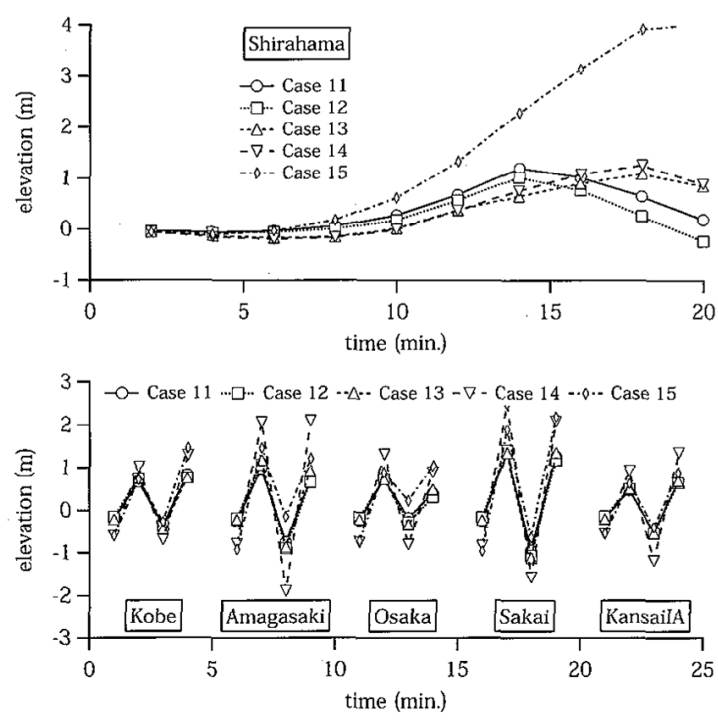

図-4 白浜観測塔における時間波形と大阪湾内 5 地点に おりる水位低下量と上昇量
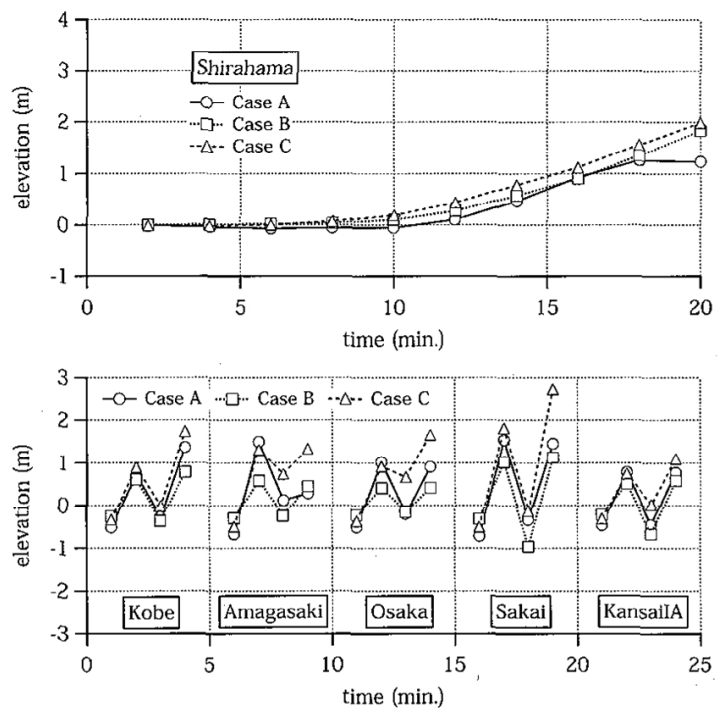

図-5 テストケースの時間波形と水位低下量, 上昇量

ヨン結果である。

少なくとも訓練データをうまく整理することができ， テストケースに対して予測できることが必要である，中 央防災会議による東南海・南海地震モデルは，テストケ 一スとしてだけでなく，訓練データとしても用い，その 相違を調べた。

\section{4. ニューラルネットワークによる津波予測}

\section{(1) ニューラルネットワークの設定}

過学習を防ぐため，また，今回用いるケース数が少な いため，バリデーションデータを用いなくてもよい最適 


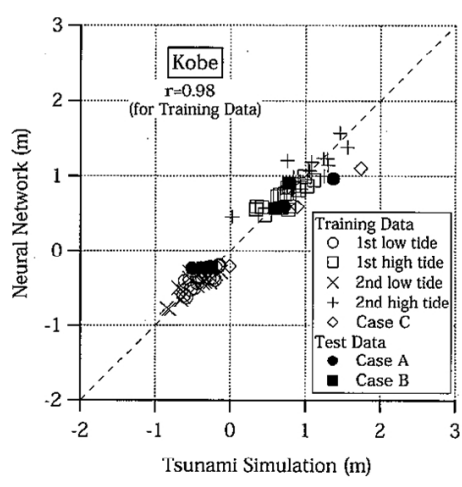

（a) 神戸港

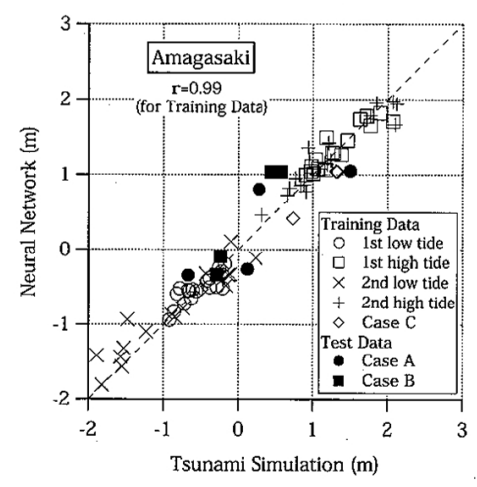

(b) 尼崎港

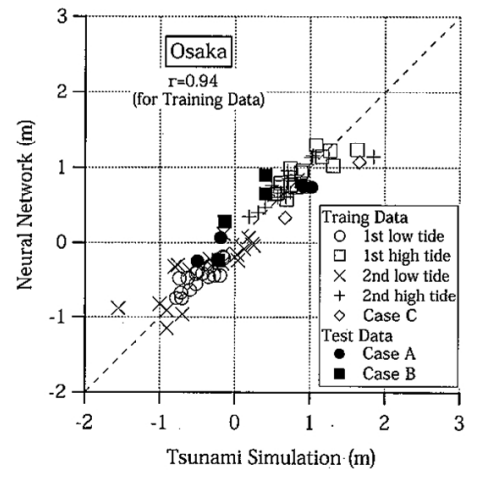

(c) 大阪港

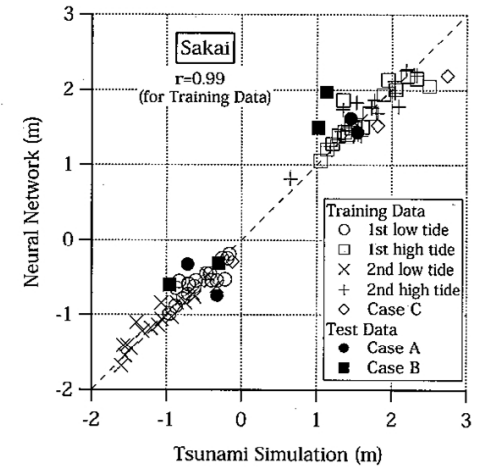

(d) 堺泉北港

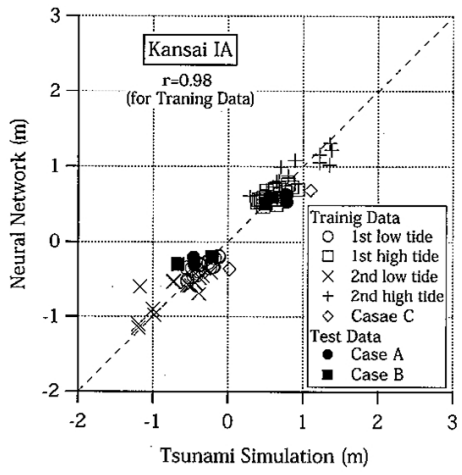

(e) 関西空港

図-6 ニューラルネットワークによる予测結果

Bayesian 正則化法と高速訓練アルゴリズム LM 法の組 み合わせを用いた。

中間層は $5,10,20$ 個の 3 ケース, 中間層に用いる応 答関数として, tangent 型シグモイド関数と $\log$ 型シグ モイド関数の 2 ケース, 出力層の応答関数として, tangent 型, log 型, linear 関数の 3 ケースを考え, それぞ れの組み合わせを用いた訓練を行った。

入力パターンとして白浜钼測塔での 0 〜 20 分までの 2 分おきの波形データ 10 個, 出力值として, 対象地点 の第 1 波および第 2 波の最大水位上昇量とおよび水位低 下量の 4 つを, 各地点毎, あるいは, 5 地点全部に対し て出力する. 各地点每に津波計算値とニューラルネット ワークによる予測值の対応を調べ，予測に適したネット ワークのパラメータを決定した. その結果は, 以下のよ うであった。

1）出力層ユニットには, 線形関数を用いるのが良い.

2) 中間層エニットには, tangent 型シグモイド関数 を用いるのがよい.

3）中間層ユニットを 5 個とした場合は，10個およ び 20 個を用いた結果と比べて良くない.しかし， 10 個と 20 個を用いる結果にはほとんど差はみられ
ないので, 訓練回数の少ない 10 個とする.

（2）ニューラルネットワークによる予測精度の検討

まず, Case C の中央防災会議による東南海・南海地 震モデルを除いてネットワークを訓練し, Case C に対 して予測を行った結果は, シミュレーション結果との対 応がそれほどよくなかった．このモデル地震は今後起こ るであろう地震として提案されているので, 少なくとも この断層モデルによる津波は整理できなければならない と考え, 訓練データとして用いることとした。

図-6は，5地点毎にニューラルネットワークによる予 測值 (縦軸) と津波シミュレーション值（横軸）を比較 したものである. 1 つの図面に第 1 波および第 2 波の最 大水位上昇量と低下量をすべてプロットしてある。

図-6から，訓練データとして用いた津波の計算結果 はうまく整理できること，テストデータとして用いた Case A と Case B のそれぞれ 1707 年宝永東海・南海地 震および 1946 年昭和南海地震による津波に対して良く 予測できることがわかる。

図-7 は全 5 地点の水位上昇量および低下量に対して, Baysian 正則化法にて自動的に訓練されたネットワーク を用いて予测を行った結果と, 津波シミュレーション結 


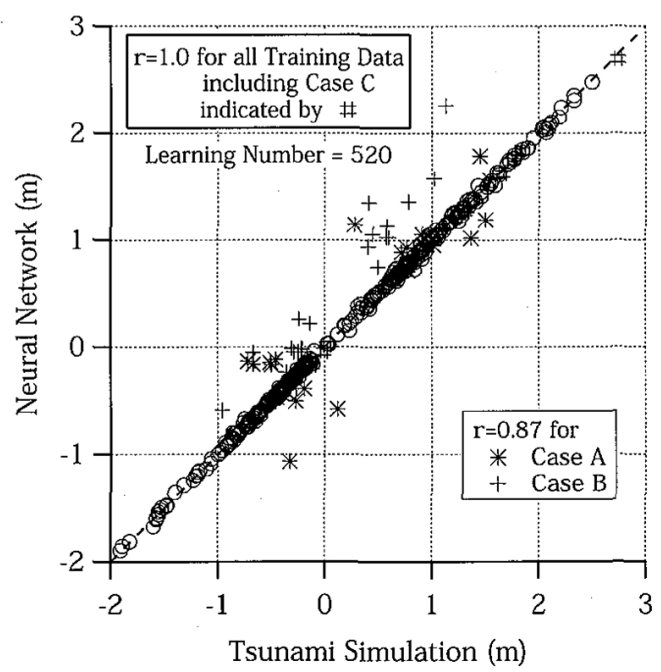

図-7 訓練回数を自動化したときの全 5 地点におけるこ ューラルネットワークによる予測値と津波シミュ レーション值の比較

果を比較したものである．訓練デー夕には Case C を加 えた。訓練回数は 520 回となり，訓練データに対しては 相関係数がほぼ 1.0 となるほど一致がよいが，テストデ 一タに対しては，相関係数が 0.87 となって雨者の対応 が悪くなる.

図-8 は訓練回数を強制的に 100 回としたもので, 図-7と比較して，訓練デー夕に対する相関は少し小さ くなり両者の分布幅が若干広がるが，テストデー夕に対 する相関係数は 0.91 と大きく, 図のように良い対応関 係が見られる。

\section{5. と め}

本研究は，来襲津波の時間波の情報は無視するが，即 座に大阪湾内への来襲津波の規模を推定する方法として, ニューラルネットワークを援用したリアルタイム津波予 測法の検討を行ったものである. 本研究で得られた主要 な結諭は, 以下の通りである.

(1)津波予測に用いるネットワークは，中間層ユニット の数が 10 , 中間層ユニットの応答関数が tansig 型, 出力層ユニットの応答関数が linear 関数である.

(2)各地点毎に, ニューラルネットワークによる引波扔 よび押波の予測值と津波シミュレーション結果を比較 した結果，両者は良く一致する。

（3） 5 地点に打ける引波と押波を同時予測するように訓 練したニューラルネットワークはうまく機能する.

今回は白浜観測塔のデータを用いたが, 到達時間の観 点からは，より外洋の観測結果を用いるのが良い。その 他に, 多地点のより短い観測時間波形を用いる場合の検 討，GPS 津波計の観測データの活用方法，実際に観測

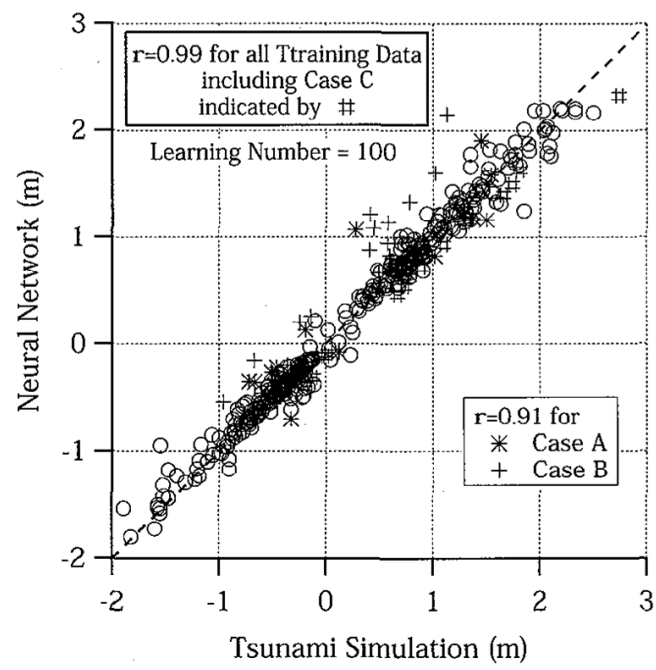

図-8 訓練回数を制限したときの全 5 地点におけるニュ ーラルネットワークによる予測值と津波シミュレ ーション值の比較

された波形を取り込み予測結果を配信するシステムの検 討が必要であるが，こうした予測システム構築を図る研 究を続けていく予定である.

\section{参 考 文 献}

相田 勇 (1981): 南海道沖の津波の数值実験, 東京大学地震研 究所夢報, Vol.56, pp. 713-730.

河田惠昭・奥村与志弘・高橋智幸・鈴木進吾 (2003)：アスペリ テイに起因する南海地震津波の波源不均一性に関する研 究, 海岸工学論文集, 第 50 巻, pp. 306-310.

地震調查研究推進本部地震鲖査委員会 (2001)：南海卜ラフの地 震を想定した強振動評価手法について (中間報告), 平成 13 年 12 月 7 日.

間瀬 肇(1994)：ニューラルネットワークを用いた捨石防波堤 の安定性評洒, 海岸工学論文集, 第 41 巻, pp. 761-765.

間瀬 肇・永橋俊二・Hedges, T.S. (2005): 湲傾斜護岸の越波 流量算定におけるニューラルネットワークの適用性に関 する研究, 海洋開発諭文集, 第 21 巻, pp. 593-598.

安田誠宏・高山知司・川村健太・間瀬 肇 (2005): 大阪湾内に 扔けるリアルタイム津波予測手法の検討, 海洋開発椧文 集, 第 21 巻, pp. 145-150.

安田誠宏・高山知司・川村健太 (2006)：観測データを用いたグ リーン関数重ね合わせ法によるリアルタイム津波波源域 推定法, 海岸工学諭文集, 第 53 卷, pp. 311-315.

Ando, M.(1975) : Source mechanism and tectonic significance of historical earthquakes along the Nankai Trough, Techtonophysics, Vol. 27, pp. 119-140.

Deo. M.C. and G. Chaudhar (1998) : Tide prediction using neural networks, Computer Aided Civil and Infrastructure, Vol. 13, pp. 113-120.

Deo, M.C. and N.C. Sridhar (1999) : Real time wave forecasting using neural networks, Ocean Eng., Vol. 26. No. 3, pp. 191-203. 